\title{
Abertura comercial, internacionalização e competitividade: a indústria brasileira de máquinas têxteis após os anos $1990^{1}$
}

\author{
Rogério Gomes ${ }^{2}$ \\ Eduardo Strachman ${ }^{3}$ \\ João Paulo Pieroni ${ }^{4}$ \\ Andréa de Oliveira Silva ${ }^{5}$
}

\section{Resumo}

Este artigo avalia os resultados do processo de reestruturação da indústria brasileira de máquinas têxteis, originado pelas reformas econômicas liberalizantes iniciadas no final dos anos 1980 e início dos 1990 e pelas medidas macroeconômicas que deram sustentação ao Plano Real, a partir de julho de 1994. Inicialmente, fazemos uma avaliação teórica das fontes do conhecimento e das formas de capacitação tecnológica nessa indústria. A seguir, expomos brevemente as principais características da indústria de máquinas têxteis em âmbito global. Posteriormente, direcionando a discussão para o caso brasileiro, apresentamos as especificidades da indústria têxtil, usuária daqueles bens, e do próprio setor de máquinas nacional. Através dos fluxos de comércio exterior do Brasil entre 1990 e 2004 e da variação do valor médio (US\$ FOB/KG) desses fluxos, o artigo examina as mudanças estruturais, tecnológicas e, por conseguinte, na competitividade, que culminaram na transformação da indústria brasileira de máquinas têxteis, em termos de dimensão (escala) e escopo, e em uma nova inserção internacional, agora mais especializada e subordinada.

Palavras-chave: Máquinas têxteis; Organização industrial; Política industrial - Brasil; Industrialização; Política Comercial; Política Cambial.

\section{Abstract \\ The commercial liberalization, internationalization and competitivity of the Brazilian textile machinery industry after the 1990's}

This paper assesses the results of the restructuring process of the Brazilian textile machinery industry, started in the late 1980's and beginning of the 1990's and deepened by the liberal macroeconomic policies supporting the Plano Real, since July 1994. First, we analyze theoretically

(1) Trabalho recebido em fevereiro de 2006 e aprovado em abril de 2007. Este artigo é fruto do estudo realizado no âmbito da pesquisa DPP (Diretório da Pesquisa Privada - <www.finep.gov.br/portaldpp>), em convênio GEEIN/Finep. Agradecemos as importantes observações de dois pareceristas anônimos. No entanto, e como sempre, eventuais falhas remanescentes são de nossa inteira responsabilidade.

(2) Professor do Departamento de Economia da Universidade Estadual Paulista (Unesp). Pesquisador do Grupo de Estudos em Economia Industrial (GEEIN), Departamento de Economia, FCL/CAr/Unesp, Araraquara, São Paulo, Brasil. E-mail: <rgomes@ fclar.unesp.br>.

(3) Professor do Departamento de Economia da Unesp. Pesquisador do GEEIN, Araraquara, São Paulo, Brasil. E-mail: <edstrach@fclar.unesp.br.

(4) Mestrando no Programa de Estudos Pós-Graduados em Economia Política, Pontifícia Universidade Católica de São Paulo (PUC-SP). Pesquisador do GEEIN, Araraquara, SP, Brasil. E-mail: $<$ ip.unesp@gmail.com>.

(5) Mestranda na Escola Politécnica da Universidade de São Paulo (USP). Pesquisador do GEEIN, Araraquara, São Paulo, Brasil. E-mail: <andrea_olivs@yahoo.com.br>. 
Rogério Gomes / Eduardo Strachman / João Paulo Pieroni / Andréa de Oliveira Silva

the knowledge sources and the capacitation modes in this industry. Second, we show briefly the main global characteristics of this industry. Third, we redirect our investigation to the Brazilian case, presenting the specificities of the domestic textile industry, user of those capital goods, and also of the Brazilian textile machinery industry. Making an assessment by means of the Brazilian textile machinery industry foreign trade as well as of the change in the mean prices (US\$ FOB/KG) of these trade inflows and outflows, between 1990 and 2004, the paper evaluate the structural, technological and, therefore, the competitive changes which culminated in the transformation of this industry in its dimensions (scale) and scope, and in its new international role, nowadays more specialized and subordinated.

Key words: Firm organization; Industrial policy; Industrialization; Manufacturing and service industries; Trade policy; Factor movement policy; Foreign exchange policy.

JEL L22, L52, L64, O14, O24.

\section{Introdução}

A tipologia de Pavitt (1984) sobre os padrões setoriais de mudança tecnológica procura explicitar as similaridades e diferenças entre os setores industriais quanto às fontes, usos, natureza e impactos das inovações, ou, resumidamente, a demanda dos usuários, a oferta dos fornecedores e as possibilidades de apropriação de conhecimento advindas das inovações. ${ }^{6}$ De acordo com essa interpretação, as empresas da indústria têxtil (fiação, tecelagem e confecção) podem ser caracterizadas como de fraca capacitação interna de engenharia e Pesquisa e Desenvolvimento (P\&D) e de baixa apropriação de vantagens tecnológicas. Como a fonte de tecnologia da indústria são os fornecedores especializados, especialmente os produtores de máquinas e equipamentos, as firmas da indústria têxtil enfatizam, em geral, as atividades relacionadas à qualificação profissional, à construção de marcas de renome e à propaganda.

As companhias que fornecem equipamentos especializados (onde se enquadram as firmas produtoras de máquinas têxteis) normalmente são pequenas e dependem de capacitações internas para melhorar projetos, a confiabilidade dos produtos e, principalmente, a capacidade de responder às necessidades dos usuários. Para Pavitt (1984), além das reduzidas escalas de produção das firmas de bens de capital quando comparadas às de outros setores, as características acima se devem às seguintes diferenças setoriais:

i) fontes de tecnologia: as firmas de bens de capital dependem mais dos seus clientes para obter informação e habilidades relacionadas ao desempenho operacional e ao projeto do que, por exemplo, as firmas baseadas em ciência; por isso, não acumulam as mesmas habilidades tecnológicas;

(6) A partir de dados de cerca de 2.000 inovações significativas da Grã-Bretanha no período 1945-1979, o autor estabeleceu uma taxonomia com quatro tipos de indústrias: 1) dominadas por fornecedores; 2) intensivas em produção; 3) baseadas em ciência; e 4) fornecedores especializados. 
ii) necessidades dos usuários: as empresas operam em mercados que apresentam, apenas de forma tênue, as características descritas pelo modelo do ciclo de produto; portanto as pressões para se diversificar são menores;

iii) condições de apropriabilidade: as firmas encontram dificuldades para se apropriarem dos benefícios de sua inovação devido à grande necessidade de produzirem inovações com reduzidas barreiras à entrada, resultando em gastos relativamente baixos no desenvolvimento dos produtos. Por outro lado, há que ressaltar a maturidade tecnológica dos equipamentos produzidos, o que também contribui para o baixo nível de dispêndios em $\mathrm{P} \& \mathrm{D}$, quando comparado com outros setores.

A importância do setor de máquinas têxteis para a indústria têxtil, em termos de fonte de tecnologia, é apresentada pelo próprio Pavitt (1984): aproximadamente $84 \%$ das inovações usadas no setor têxtil são provenientes dos fornecedores de equipamentos e insumos. Entretanto, os usuários sempre tiveram um papel ativo na geração de inovações. Rothwell (1982) sugere que 55\% das inovações radicais e $67 \%$ das incrementais produzidas na indústria de máquinas têxteis inglesas foram motivadas pela percepção das necessidades dos usuários, ainda que na concepção básica das inovações, sobretudo as radicais, a participação dos usuários seja reduzida.

Sigiura (1994) chega a conclusões semelhantes para a indústria no Japão: no fornecimento de informações sobre problemas relacionados ao uso contínuo de máquinas têxteis, os usuários cumprem papel primordial, sendo, muitas vezes, eles próprios os responsáveis por inovações incrementais. Em suma, mesmo quando os usuários não estão relacionados com a concepção básica das máquinas, eles são importantes no fornecimento de conhecimentos tácitos envolvidos em sua operação e melhoria incremental, de extrema importância para um melhor desempenho desses equipamentos.

Ao mesmo tempo em que o setor de máquinas "empurra tecnologia" para a indústria têxtil, esta última também age "puxando a demanda" por novos produtos e processos. Essa interação entre usuário e produtor, na cadeia têxtil, é necessária para o sucesso das inovações. No caso do setor fornecedor de máquinas têxteis, mais de 30\% das inovações foram "puxadas" pelos usuários (Pavitt, 1984). Assim, o "puxão da demanda" [demand pull], de acordo com Pavitt (1984), tinha uma influência mais forte que o "empurrão da tecnologia" [technological push], dada a forte correlação entre o aumento das atividades inovativas dos bens de capital e o crescimento dos investimentos dos usuários.

Segundo Lundvall (1988), no entanto, parte substancial das atividades inovadoras é feita em unidades separadas dos usuários da tecnologia. Porém, quando uma nova tecnologia é desenvolvida pelos produtores, a difusão só 
Rogério Gomes / Eduardo Strachman / João Paulo Pieroni / Andréa de Oliveira Silva

ocorrerá se esta for transmitida e incorporada pelos potenciais usuários. Dessa forma, deve haver uma constante interação e troca de informações entre esses agentes. Para o autor, as inovações ocorrem nos chamados mercados organizados, os quais são caracterizados por transações entre unidades formalmente independentes e com fluxos de informação, volume e preço entre elas. Nesses mercados há uma hierarquia refletindo a dominância de uma parte pela outra (usuário ou produtor), seja por poder financeiro e/ou por tecnologia e técnicas superiores.

No processo de inovação de produtos e processos, a interação entre usuário e produtor se dá a partir do monitoramento dos produtores sobre as necessidades e expectativas dos usuários devido às seguintes razões: 1) inovações de produto para os usuários provavelmente implicarão novas demandas por processos e equipamentos, vale dizer, com inovações e/ou demanda por inovações também provindo dos usuários; 2) o conhecimento produzido pelo learning-byusing somente pode ser transformado em novos produtos se os produtores tiverem contato com esses usuários; 3) a observação das tecnologias interdependentes e dos gargalos dos usuários pode representar mercados potenciais para a inovação do produtor; e 4) o produtor que acompanha o usuário pode estimar a sua capacidade de adquirir novos produtos.

Por outro lado, os usuários necessitam de informações sobre novos produtos, as quais envolvem detalhes bastante específicos para que possam atender a suas necessidades. Esse relacionamento com os produtores também é necessário quando ocorrem problemas, como aqueles que demandam assistência técnica, mudanças em produtos, sistemas, partes, etc. Em outras palavras, o usuário deve buscar conhecer em detalhes as competências e habilidades dos diferentes produtores, a fim de se cercar dos melhores entre eles, em relacionamentos virtuosos (Lundvall, 1988).

Em condições de desempenho satisfatório (Simon, 1962; 1976), a eficiência da relação usuário-produtor tende a crescer com o tempo, pela interação entre as empresas, os indivíduos que compõem sua hierarquia, a confiança e a troca de informações entre todos esses agentes. Entretanto, é possível que a relação usuário-produtor não gere atividades inovadoras ou eficientes. Isso ocorre quando o usuário ou o fornecedor são conservadores em suas iniciativas, ou quando os usuários possuem necessidades muito diversificadas, trazendo dificuldades para o produtor em termos de acumulação de experiência e escala. Não se deve esquecer também da influência de um ambiente que incentiva (ou não) a inovatividade sobre o desempenho de usuários e fornecedores nesse quesito. 
No Brasil, esta relação usuário-produtor e os resultados em termos de produtos inovadores encontram impedimentos estruturais. Segundo Hiratuka (1996), no setor têxtil a maioria dos fabricantes de máquinas não desenvolve tecnologia internamente, ou porque são filiais de companhias estrangeiras ou porque são firmas nacionais que adquirem tecnologia através de contratos com fornecedores internacionais.

Como não há um núcleo interno de geração de tecnologia consistente e permanente, qualquer tentativa de formação de acordos de colaboração tecnológica entre usuários e fornecedores do setor têxtil é dificultada. Contudo, existem exceções, como a de uma empresa de máquinas que considera a interação com os usuários, através de contatos e troca de informações, muito relevante, pois, por meio destes, a empresa consegue adaptar a máquina às características específicas de cada usuário, melhorando o desempenho de seus equipamentos e, como consequiência, aumentando a produtividade desses usuários, gerando-lhes externalidades positivas em termos de inovações, ainda que incrementais.

Outro caso verificado em entrevista realizada ${ }^{7}$ foi o de um fabricante de equipamentos têxteis razoavelmente simples, mas que possui criatividade suficiente para conseguir uma série de inovações incrementais, inclusive com patentes no Brasil. Vale dizer, esse comportamento inovador fortemente incremental pode ser percebido em uma série de produtores de máquinas têxteis.

O setor de máquinas têxteis no Brasil é um caso emblemático da inserção de setores de alta tecnologia na estrutura produtiva mundial. A partir dos anos 1990, os efeitos negativos da elevada proteção governamental das décadas anteriores, as políticas econômicas adotadas e a dinâmica mundial do setor voltada à relocalização e concentração de etapas da produção que envolvem maior capacitação nos países centrais - repercutiram negativamente sobre a agregação de tecnologias e o bom desempenho do setor no Brasil, o que restringiu os impactos positivos das relações estabelecidas entre os usuários e produtores de máquinas têxteis no país.

Este artigo examina, a partir das transformações ocorridas na estrutura produtiva e de comércio, a evolução dos segmentos do setor de máquinas para a indústria têxtil do Brasil, nos últimos quinze anos. Como apresentado acima, em virtude de seu papel de difusor de tecnologias, o desempenho e as tendências aqui

(7) Todas as entrevistas mencionadas neste artigo foram realizadas por pesquisadores do Grupo de Estudos de Economia Industrial, da Universidade Estadual Paulista (GEEIN/Unesp), para um estudo mais amplo sobre bens de capital, o qual inclui aqueles destinados à indústria têxtil. Esta pesquisa foi realizada no âmbito da pesquisa DPP (Diretório da Pesquisa Privada - www.finep.gov.br/portaldpp), em convênio GEEIN/Finep, recebendo apoio também de Projeto de Iniciação Científica da Fundação de Amparo à Pesquisa do Estado de São Paulo (Fapesp), no ano de 2005. 
Rogério Gomes / Eduardo Strachman / João Paulo Pieroni / Andréa de Oliveira Silva

vislumbradas para indústria de bens de capital para a indústria têxtil têm papel fundamental para o desenvolvimento da cadeia têxtil.

Além desta introdução, este artigo apresenta no item 1 as características principais da indústria de máquinas têxteis no cenário mundial. Na seção 2 são destacados os aspectos mais relevantes da indústria têxtil para a análise do comportamento do segmento de máquinas, enquanto nos itens 3 e 4 apresenta-se o cerne deste estudo, com um detalhamento do desenvolvimento e do desempenho recente do setor de máquinas têxteis. $\mathrm{O}$ item 3 apresenta um breve histórico da instalação da indústria no Brasil e do grau de especialização tecnológica do país antes da abertura econômica. $\mathrm{O}$ item seguinte destaca os impactos da abertura comercial sobre o setor de máquinas têxteis, ressaltando os seguintes pontos: a) as alterações na estrutura organizacional de cada etapa do setor (mostrando em quais segmentos as empresas continuaram atuando no Brasil e aqueles em que a produção foi cessada); b) os ganhos de capacitação tecnológica dos segmentos de máquinas; c) os dados de comércio, por segmento e d) as alterações na última década e meia do conteúdo tecnológico no comércio exterior de máquinas têxteis.

A conclusão é apresentada na seqüência, considerando-se que a abertura comercial e as políticas econômicas adotadas recentemente, associadas à dinâmica produtiva mundial, parecem ter imprimido três efeitos principais sobre a capacitação dos segmentos e das empresas de máquinas para a indústria têxtil nacional: i) o setor de máquinas têxteis brasileiro tem seguido o padrão mundial, desativando etapas de produção que demandam maior conteúdo tecnológico, os quais estão concentrados principalmente nos países europeus; ii) houve, de fato, uma regressão da pauta comercial brasileira deste setor em direção a uma maior exportação de peças, partes e componentes, resultando em uma inserção mais subordinada no comércio internacional; e iii) mesmo naqueles segmentos beneficiados com um efetivo aumento do conteúdo tecnológico agregado às exportações, há sinais de direcionamento para a produção de acessórios de máquinas, isto é, de crescimento mais do que proporcional da participação das exportações de acessórios de máquinas no interior das exportações totais desses segmentos.

\section{Características internacionais do segmento de máquinas para a indústria têxtil}

No segmento de máquinas têxteis, o processo de modernização internacional deu-se a partir da década de 1970, com a inserção da microeletrônica nas máquinas, que por sua vez se refletiu em diminuição dos níveis de emprego e aumento da produtividade. A partir daquele período, a tendência do setor foi de aumentar a automação em cada uma das etapas produtivas (Massuda, 2002). 
Quadro 1

Etapas do desenvolvimento tecnológico das máquinas para a indústria têxtil

\begin{tabular}{|c|c|c|c|}
\hline \multicolumn{2}{|c|}{ Período } & \multirow{2}{*}{ Fonte da Inovação } & \multirow{2}{*}{ Características } \\
\hline Início aproximado & Até os anos & & \\
\hline $\begin{array}{l}\text { Começo do séc. XIX } \\
(1820)\end{array}$ & $\begin{array}{l}1930 \text { do séc. } \\
\text { XX }\end{array}$ & Usuário & $\begin{array}{l}\text { Relação entre a indústria têxtil e a de } \\
\text { máquinas é crucial; inovações radicais. }\end{array}$ \\
\hline Anos 1930 & 1960 & $\begin{array}{l}\text { P\&D nas firmas } \\
\text { produtoras de } \\
\text { máquinas }\end{array}$ & $\begin{array}{c}\text { Aumento da velocidade do equipamento } \\
\text { devido à maior resistência dos fios } \\
\text { artificiais. }\end{array}$ \\
\hline Anos 1960 & 1980 & $\begin{array}{l}\text { P\&D nas firmas } \\
\text { produtoras de } \\
\text { máquinas }\end{array}$ & $\begin{array}{l}\text { Redução da descontinuidade do processo } \\
\text { produtivo; aumento da velocidade e da } \\
\text { produtividade. }\end{array}$ \\
\hline Anos 1980 & --- & $\begin{array}{l}\text { P\&D nas firmas } \\
\text { produtoras de } \\
\text { máquinas }\end{array}$ & $\begin{array}{c}\text { Incorporação da microeletrônica nos } \\
\text { equipamentos; continuidade dos avanços } \\
\text { da fase anterior. }\end{array}$ \\
\hline
\end{tabular}

Fonte: Elaboração GEEIN, a partir de Rothwell (1982), Toyne (1984), Sigiura (1994) e Hiratuka (1996).

O mercado de máquinas têxteis mundial é bastante concentrado em algumas regiões e os principais fabricantes estão localizados nos países desenvolvidos. Em geral, as firmas são bastante especializadas, concentrando-se em etapas específicas do processo têxtil. Por isso, as empresas de máquinas são pequenas, quando comparadas a firmas de outras indústrias. Na quase totalidade dos casos, o faturamento anual e o número de funcionários das maiores empresas não ultrapassam US $\$ 2$ bilhões e 2.000 empregados, respectivamente.

No período recente, o comércio internacional do setor de máquinas e equipamentos para a indústria têxtil tem movimentado em torno de US\$ 15 bilhões ao ano. ${ }^{8}$ A produção e as exportações são bastante concentradas em, basicamente, quatro países: Alemanha, Japão, Itália e Suíça. Em conjunto, esses países representaram mais de 65\% do comércio mundial dessas máquinas em 2001. Outros exportadores relevantes, mas com importância relativamente menor, são França, EUA e Reino Unido. Por outro lado, as importações são mais dispersas, tendo os EUA, China e Índia como os maiores compradores de máquinas (40\% das importações mundiais), além dos principais países exportadores, que também importam valores consideráveis desses produtos.

A participação do Brasil nas exportações mundiais de máquinas têxteis é baixa, com cerca de $0,45 \%$ das vendas internacionais em média, entre os anos de 1997 e 2001. Embora esse valor seja pequeno, o Brasil é um dos poucos países em desenvolvimento a participar do comércio desses produtos. Por outro lado, as importações brasileiras são bem mais expressivas. Aproximadamente 3,5\% das

(8) Os dados apresentados nesta seção são da UNCTAD e foram calculados pelos autores a partir do programa PC-TAS, para os anos de 1997 a 2001. 
Rogério Gomes / Eduardo Strachman / João Paulo Pieroni / Andréa de Oliveira Silva

vendas mundiais são destinadas ao país, especialmente aquelas de teares mais avançados.

O forte movimento da indústria têxtil mundial em direção à região sudeste da Ásia, em especial para a China, na busca por custos mais baixos de produção, não foi acompanhado de forma significativa pelo segmento de máquinas têxteis. As revistas e os periódicos especializados indicam que as indústrias de máquinas continuam atendendo o aumento da demanda, sobretudo por meio de exportações. Os escritórios de representação e a participação em feiras internacionais continuam sendo a principal estratégia de divulgação dos produtos no estrangeiro (Revista Textília, n. 40).

\section{Aspectos da indústria têxtil do Brasil}

É importante observar as características da indústria têxtil, usuária das máquinas, no Brasil, pois estas irão influir de forma decisiva no processo de desenvolvimento e geração de tecnologia no setor de máquinas, dada a forte correlação, exposta acima, entre usuários e produtores de equipamentos.

A cadeia têxtil caracteriza-se pela descontinuidade entre os seus vários segmentos. Como o produto final de uma etapa constitui-se na matéria-prima para a fase seguinte, cada um dos segmentos possui dinâmica própria, com especificidades tecnológicas de mercado e de matérias-primas, o que se reflete na produção com diferentes níveis de especialização dos segmentos constituintes do setor. Por outro lado, a interdependência entre as etapas produtivas não ocorre no relacionamento técnico entre as empresas, o que permite a coexistência de equipamentos modernos e obsoletos nos diversos segmentos ou até mesmo numa mesma fábrica.

A indústria têxtil no Brasil é bastante heterogênea, com alguns segmentos bastante competitivos - formados por grandes empresas integradas e com alto índice de mecanização - convivendo com outros que apresentam significativas deficiências neste quesito (em especial o de confecções), seja pelas reduzidas escalas produtiva e empresarial, seja pelo alto grau de informalidade ou, ainda, pelas fraquezas tecnológicas (Vermulm; Erber, 2002).

O Brasil está entre os 10 maiores produtores mundiais de fios/filamentos, tecidos e malhas, especialmente de algodão. Neste último segmento - malhas com predominância de algodão - o país é atualmente o terceiro maior produtor mundial. Os tecidos e confeccionados de algodão são os principais itens de exportação da indústria têxtil brasileira, com participação de $58 \%$ das vendas

externas têxteis brasileiras em 1999, especialmente o denim, para a confecção de jeans, e os artigos de cama, mesa e banho. 
Todavia, quando consideramos a produção de fibras artificiais e sintéticas, o mercado brasileiro ainda é pouco desenvolvido. Neste segmento, o Brasil possui apenas $1 \%$ da capacidade produtiva mundial, que o torna um grande importador destes produtos (Gorini, 2000).

\section{A indústria de máquinas têxteis no Brasil}

\subsection{Um breve histórico}

A instalação da indústria de máquinas e equipamentos têxteis no Brasil tem origem na década de 1920, podendo ser considerada uma das primeiras indústrias mecânicas a se estabelecerem no país. Porém, a falta de proteção para a indústria nascente contra as importações de bens de capital nos governos subsequientes dificultou o seu crescimento. Somente a partir dos anos 1960 o setor apresentou um maior desenvolvimento, com o Estado passando a estimular a indústria nacional, através de programas de financiamento subsidiado.

Por meio de incentivo à modernização do parque industrial, via crédito fácil e barato, altas tarifas de importação de equipamentos completos e isenções fiscais para a importação de partes e peças necessárias à produção interna, a indústria brasileira de máquinas têxteis ganhou grande impulso na década de 1970. Segundo Bastos (1993), esse processo de substituição de importações permitiu que o Brasil se tornasse, juntamente com a Coréia, um dos únicos países em desenvolvimento com capacidade produtiva expressiva em máquinas e equipamentos para o complexo têxtil.

A crise nos anos 1980, que resultou em baixo crescimento da economia brasileira e em elevada variação de investimentos na indústria têxtil, não permitiu que a capacidade produtiva e a capacitação tecnológica do segmento de máquinas evoluíssem favoravelmente de forma consistente. Além disso, no final da década foi estabelecida uma agenda de redução das barreiras legais à importação, que se refletiu em acréscimo significativo das máquinas adquiridas no exterior.

Ao final da década de 1980, a indústria de máquinas era composta por cerca de 140 empresas, envolvendo um número total em torno de 3.000 trabalhadores (Garcia, 1993). Apesar desse número considerável e da grande segmentação do mercado, algumas poucas firmas dominavam os diversos segmentos. A maioria dessas empresas eram filiais de multinacionais estrangeiras ou firmas nacionais que possuíam algum contrato de transferência de tecnologia com grandes fabricantes mundiais.

Para os fabricantes domésticos, em seu conjunto, o próprio mercado interno representava a principal fonte de demanda, porém as exportações 
(principalmente para a Europa, Estados Unidos e América Latina) eram importantes para suprir não só os períodos de baixo dinamismo do mercado local e as fortes flutuações da demanda, mas também para superar os limites da baixa escala de produção. Nos anos 1980, as principais dificuldades apresentadas pelas empresas brasileiras para o aumento do conteúdo tecnológico dos seus produtos foram o alto custo das matérias-primas e as políticas protecionistas do Estado, que dificultavam a importação de componentes microeletrônicos sem similares fabricados no Brasil.

No início dos anos 1990 novamente as alíquotas de importação passaram por um rápido processo de redução, fato que incentivou os investimentos na indústria têxtil. No entanto, o auge da modernização ocorreu com a apreciação da moeda nacional (entre 1994 e 1998), a partir da implementação do Plano Real. ${ }^{9}$ As políticas macroeconômica e industrial repercutiram em redução dos preços relativos das importações e favoreceram não só as compras de máquinas no exterior, mas também determinaram a elevação da demanda por produtos importados, acirrando a concorrência interna. Esses aspectos somados promoveram a reorganização da indústria brasileira - também em seu setor de máquinas têxteis - tendo como uma de suas principais características a exposição à concorrência internacional num prazo extremamente curto, dificultando qualquer processo de adaptação a um novo ambiente.

Em suma, o segmento de máquinas têxteis do Brasil transitou da condição de elevada proteção industrial, nos anos 1980, para outra de acirrada concorrência externa na década de 1990, sobretudo em sua segunda metade, razão de sua rápida fragilização.

$\mathrm{O}$ aumento de consumo de produtos têxteis causado pela estabilização e elevação da renda real também foi um importante fator para o aumento das importações brasileiras de máquinas e equipamentos, a partir de 1994. Ao mesmo tempo, a aquisição de máquinas têxteis foi incentivada pelo governo por meio de um programa especial de ampliação do crédito, promovendo a obsolescência do parque industrial instalado, reforçando ou iniciando, dependendo do segmento da indústria têxtil, as inversões em máquinas. Esse processo pode ser percebido na Tabela 1.

(9) O Plano Real, de 1994, que visava prioritariamente a alcançar a estabilidade monetária, combinou dois elementos de política econômica: taxa de câmbio apreciada e taxas de juro elevadas. Enquanto o primeiro garantia o controle de preços pelo barateamento dos produtos importados, o segundo atraía capitais financeiros que permitiam fechar o Balanço de Pagamentos, cobrindo os déficits na balança comercial. Essas políticas provocaram uma forte reestruturação na indústria, alterando a competitividade das empresas e o modo de inserção internacional do país em vários setores industriais. 
Tabela 1

Produção e consumo aparente de máquinas têxteis no Brasil:

\begin{tabular}{l|c|c|c}
\multicolumn{4}{|c}{$1990-1998$ (US\$ milhões) } \\
\hline \multirow{2}{*}{ Ano } & $\begin{array}{c}\text { Produção } \\
\text { Nacional } \\
\text { (A) }\end{array}$ & $\begin{array}{c}\text { Consumo } \\
\text { Aparente } \\
(B)\end{array}$ & $\begin{array}{c}\text { A/B } \\
(\%)\end{array}$ \\
\hline 1990 & 336,0 & 684,0 & 49,1 \\
\hline 1991 & 272,0 & 576,2 & 47,2 \\
\hline 1992 & 254,0 & 662,5 & 38,3 \\
\hline 1993 & 308,6 & 584,0 & 52,8 \\
\hline 1994 & 352,8 & 798,6 & 44,2 \\
\hline 1995 & 357,4 & $1.005,2$ & 35,6 \\
\hline 1996 & 296,6 & 704,6 & 42,1 \\
\hline 1997 & 293,3 & 808,0 & 36,3 \\
\hline 1998 & 275,4 & 667,5 & 41,3 \\
\hline
\end{tabular}

Fonte: Abimaq - Extraída de CNI (2000).

Em termos de inovações, as poucas que surgem são incrementais e provêm, principalmente, da percepção das necessidades dos clientes, como ressalta a primeira parte do artigo. Também nas entrevistas o relacionamento com os usuários mostrou-se bastante relevante. Por exemplo, para a empresa produtora de ramas, com máquinas cujo tamanho é bastante elevado (cerca de 60 metros), são os usuários que identificam os problemas durante a operação dos equipamentos, sugerindo melhorias aos fabricantes. Estes, por sua vez, ao desenvolverem tais modificações e aperfeiçoamentos, muitas vezes acabam por incorporá-los perenemente às suas linhas de produtos.

As relações de assistência técnica são igualmente importantes para todas as empresas entrevistadas. Assim, ao vender uma máquina para a indústria têxtil, os fabricantes treinam os operários dessa empresa e oferecem assistência técnica gratuita. Essa relação é, em muitos casos, benéfica para ambas as partes, sendo primordial para a dinâmica do setor de máquinas têxteis, especialmente no Brasil.

\subsection{Nível tecnológico e de competitividade das máquinas têxteis no período anterior à abertura comercial}

O nível tecnológico das máquinas e acessórios têxteis produzidos no Brasil pode ser avaliado através das diversas etapas do processo produtivo da indústria têxtil. No período anterior à abertura comercial (até o final da década de 1980), no segmento para fiação, no qual se encontram cardadeiras, passadeiras, maçaroqueiras, filatórios e conicaleiras, apenas os fabricantes nacionais de cardas acompanhavam com uma defasagem pequena a tecnologia dos grandes produtores internacionais. Nos outros tipos de máquinas, o Brasil possuía deficiências 
tecnológicas, o que acabou levando ao fechamento de grande parte dos fabricantes durante a década de 1990 (ver Quadro 2).

Segundo Hiratuka (1992), na etapa de acabamento as empresas produtoras no país apresentavam os melhores resultados em comparação com seus concorrentes estrangeiros. A qualidade das máquinas nacionais era bastante semelhante à das máquinas importadas. Neste segmento, ao contrário do anterior, não existe uma seqüência de máquina pela qual o produto final deva passar obrigatoriamente. As máquinas utilizadas dependem apenas de qual espécie de acabamento se pretenda dar ao tecido, o que torna esses aparelhos independentes tecnologicamente dos demais e do processo produtivo como um todo.

No segmento de teares, os fabricados no Brasil não eram automatizados, não incorporando, portanto, as novas tecnologias que envolviam softwares específicos para sua operação. Por isso, existiam fortes pressões para o abandono da produção de teares obsoletos. A abertura comercial conduziu a uma forte concorrência por parte das importadoras de máquinas têxteis, tornando inviável a produção local de bens de maior conteúdo tecnológico no país, visto que os próprios demandantes de máquinas exigem produtos compatíveis com aqueles utilizados por seus concorrentes estrangeiros. Entre as máquinas para malharia, à exceção de teares circulares, com uma única empresa no país, todos os outros tipos de máquina são importados (CNI, 2000).

Por esses aspectos, Vermulm e Erber (2002) concluíram que a tendência da indústria de máquinas têxteis brasileira seria a de fabricação de partes, peças e componentes para os equipamentos tecnologicamente avançados, visando tanto ao mercado interno quanto aos países da América do Sul. Contudo, há ainda hoje no país diversas empresas nacionais e estrangeiras que fabricam máquinas têxteis completas e que se reestruturaram com a abertura comercial. Dentre as áreas do processo produtivo têxtil em que atuam estas empresas, podem ser citadas: abertura de fardos, urdideiras, engomadeiras de fios, teares circulares e máquinas para o beneficiamento de malharia, com fortes vínculos com a produção têxtil com base em fibra natural.

\section{Impactos da abertura comercial sobre a indústria de máquinas têxteis no Brasil}

Há evidências de que as empresas de equipamentos para a indústria têxtil, em âmbito mundial, estejam se concentrando em países que dispõem de elevado potencial de desenvolvimento de novas tecnologias, os quais precisam atingir elevada escala de vendas para viabilizar investimentos em P\&D. ${ }^{10}$ Associada a essa tendência, a abertura comercial brasileira acelerada e sem salvaguardas

(10) Apenas no período 1998 a 2002, foram constatadas cinco Fusões e Aquisições entre as maiores empresas mundiais de máquinas têxteis, sempre visando a integrar suas fábricas nos países centrais. 
parecem ter implicado a redução do setor de máquinas têxteis do país (ver Quadro 2), com diversos casos de fechamento de empresas por falência ou de unidades para diminuição da gama de produtos fabricados.

No Quadro 2 nota-se a redução do número de empresas no Brasil. As máquinas passadeiras, maçaroqueiras, filatórios, conicaleiras, teares a jato de ar e teares a pinça são alguns exemplos de equipamentos que anteriormente eram produzidas no país, mas que tiveram a sua produção cessada. A maioria dessas máquinas correspondia à etapa de fiação, aparentemente, o segmento mais afetado com a diminuição do número de empresas de máquinas têxteis no país.

Quadro 2

Alterações na estrutura do setor de máquinas têxteis no Brasil: Número de empresas, 1989 e 2004

\begin{tabular}{|c|c|c|c|}
\hline $\begin{array}{l}\text { Processo } \\
\text { produtivo têxtil }\end{array}$ & Máquina & 1989 & 2004 \\
\hline \multirow{4}{*}{ Fiação } & Cardas & 1 (Trutzschler) & 1 (Trutzschler, Alemanha) \\
\hline & Passadeira & 2 & 0 \\
\hline & Maçaroqueiras & 2 & 0 \\
\hline & Filatórios & 3 & 0 \\
\hline \multirow{3}{*}{$\begin{array}{l}\text { Preparação para a } \\
\text { Tecelagem }\end{array}$} & Conicaleira & 2 & 0 \\
\hline & Urdideiras & $\begin{array}{c}2 \text { (Petersen Santa Clara e } \\
\text { Comelato) }\end{array}$ & $\begin{array}{c}2 \text { (Petersen Santa Clara e } \\
\text { Comelato, Brasil) }\end{array}$ \\
\hline & Engomadeira de fios & 1 (Texima) & 1 (Texima, Brasil) \\
\hline \multirow{2}{*}{$\begin{array}{l}\text { Teares para trama } \\
\text { e urdume }\end{array}$} & Teares a jato de ar & 1 (Brasil) & 1 (Toyota, Japão) $^{(1)}$ \\
\hline & Teares de pinça & $\begin{array}{c}3 \text { (Howa, Japão, Ribeiro, } \\
\text { Brasil) }\end{array}$ & 0 \\
\hline \multirow{3}{*}{$\begin{array}{l}\text { Fabricação de } \\
\text { malhas }\end{array}$} & Teares para malhas & 1 (Avanço) & 1 (Avanço, Itália) \\
\hline & $\begin{array}{l}\text { Máquinas para } \\
\text { acabamento }\end{array}$ & 1 (Texima) & $\begin{array}{c}2 \text { (Texima e Albrecht, } \\
\text { Brasil) }\end{array}$ \\
\hline & Máquinas para estamparia & 0 & 0 \\
\hline $\begin{array}{l}\text { Beneficiamento de } \\
\text { malharia }\end{array}$ & $\begin{array}{c}\text { Máquinas para } \\
\text { centrifugação e pressão }\end{array}$ & 1 (Indstel) & 1 (Indstel, Brasil) \\
\hline
\end{tabular}

(1) Não foi possível verificar se esses produtos serão produzidos no país ou apenas importados da matriz da empresa

Obs: Descritas apenas as principais empresas de cada etapa. O nome da firma é seguido pela origem do capital. Fonte: Elaboração GEEIN a partir de CNI (2004), Revista Textília, Revista Têxtil, Catálogo de Exportadores CNI e Sítios das empresas. 
Este fenômeno não teve como contrapartida a entrada de empresas estrangeiras no Brasil, ${ }^{11}$ resultado que comprova a forte tendência de centralização das grandes firmas nos países desenvolvidos, opondo-se ao processo de internacionalização da produção presente em outros setores. Nem mesmo houve um número significativo de fusões e aquisições ${ }^{12}$ no mercado doméstico, uma característica peculiar da globalização e do processo vivenciado por outras indústrias do país no período posterior à abertura comercial.

Em 2003, o setor de máquinas têxteis possuía um total de 80 empresas, e o faturamento do setor atingiu US\$ 200 milhões, sendo que 12,5\% (US\$ 25 milhões) eram exportados (Revista Textília, n. 40; Marrone, 2004).

A seção seguinte analisa o período posterior à abertura comercial, após 1990, subdividido em três períodos: 1) de 1990 a 1993, quando ocorrem a desregulamentação e a redução das alíquotas de importação; 2) entre 1994 e 1998, fase de apreciação do Real; 3) a partir de 1999, ano que o Real sofreu forte desvalorização perante o dólar e época em que a indústria brasileira já havia assimilado parte dos impactos anteriores, havendo ultrapassado a fase mais densa da reestruturação. ${ }^{13}$ Além das ponderações feitas nos itens anteriores, as considerações sobre as estatísticas apresentadas incorporam informações obtidas em entrevistas presenciais.

\subsection{Competitividade e capacitação tecnológica do setor de máquinas têxteis no Brasil: uma análise comparativa através do conteúdo tecnológico do comércio exterior brasileiro}

Neste item procuramos apreender o atual grau tecnológico do segmento de máquinas para a indústria têxtil do Brasil, numa análise através do comércio exterior do país nos três períodos definidos acima. Neste estudo, consideramos estritamente os códigos que se referem às máquinas, equipamentos, partes e acessórios têxteis - códigos 8444 a 8448, 8451 (partes) e 8452 da Nomenclatura Comum do Mercosul (NCM).

(11) A entrada em 2005 da Toyota Industries Corporation na produção de teares a jato, penteadeiras e maçaroqueiras - visando à proximidade com os clientes e ao estabelecimento de uma plataforma de exportações para a América do Sul - foi o único caso registrado de ingresso de capital estrangeiro no setor.

(12) A única aquisição foi a da subsidiária da Hollingsworth (EUA) pela alemã Trutzschler, no valor de R\$ 4 milhões, em 2003. As cardas, produzidas pela empresa européia, são utilizadas nas etapas iniciais da fiação e realizam suas funções em um processo mecânico que se passa entre seus principais componentes, os quais são revestidos por guarnições rígidas ou flexíveis. Ambas as guarnições eram produzidas pela Hollingsworth, mostrando que o objetivo principal da fusão foi a busca por maior verticalização na produção e sinergia entre os produtos.

(13) A agregação dos dados de comércio exterior e do indicador de conteúdo tecnológico (Valor Médio) nesses três períodos tem dupla função: a) confrontar os resultados das diferentes políticas micro e macroeconômicas (especialmente a de câmbio) empregadas em cada período; b) tentar contornar as fortes oscilações nos valores das estatísticas, uma característica comum do setor de bens de capital. 
O indicador empregado para a análise do conteúdo tecnológico do comércio exterior é o do valor médio dos bens transacionados pelo Brasil com o estrangeiro. $\mathrm{O}$ valor médio - um indicador da tecnologia incorporada nos produtos exportados e importados - é o quociente entre o valor (em US\$ FOB) e o peso (em $\mathrm{kg}$ ) dos vários itens do fluxo de comércio. $\mathrm{O}$ valor médio pressupõe que, em geral, os produtos de valor adicionado mais elevado são aqueles que mais incorporam conteúdo tecnológico (Gomes; Rodrigues; Carvalho, 2005).

Como a análise é feita para um período longo, com intensas flutuações que se refletem nas relações entre preços e câmbio, é apresentada também a proporção entre o valor médio das exportações e o das importações. Esse indicador, pensado em termos de países ou indústrias, pode ser interpretado como uma medida da "competitividade tecnológica" ou do "nível de desenvolvimento tecnológico do setor": quanto maior este seja do que a unidade (1), mais competitivo é o setor/indústria/ramo/segmento analisado; em contrapartida, quanto menor este seja em relação à mesma unidade, menos competitivo é o setor/indústria/ramo/ segmento.

É importante destacar que tanto os valores das exportações como os das importações de bens de capital são, em geral, muito voláteis em razão dos ciclos de investimentos. Por isso, os dados foram acumulados para cada um dos três distintos períodos analisados. ${ }^{14}$ Além disso, o fato de os valores médios das máquinas importadas serem bastante superiores aos das exportadas é um forte indicativo da fragilidade tecnológica dos produtos produzidos no Brasil.

Uma outra característica marcante do comércio exterior do Brasil no segmento é o déficit estrutural da balança comercial, agravado pela apreciação do Real e reestruturação industrial na primeira fase do Plano (1994-1998). Em todo o período, os blocos econômicos mais importantes para as exportações brasileiras foram a União Européia (UE) e o Nafta, com vendas externas em torno de $48 \%$ e $17 \%$, respectivamente. Também em relação às importações, a UE foi o principal fornecedor de equipamentos para o país $(60 \%)$, seguida pelo Nafta $(6 \%){ }^{15}$

$\mathrm{Na}$ Europa estão sediadas as matrizes da grande maioria das empresas multinacionais do setor de máquinas têxteis instaladas no Brasil. Este último fato, considerado em conjunto com as relações comerciais privilegiadas (mais intensas) com a região, é um forte indicativo de comércio intrafirma, porém profundamente assimétrico e desfavorável ao Brasil.

É possível, igualmente, explicar o comportamento excepcional do comércio exterior brasileiro de máquinas têxteis (como pode ser visto nas Tabelas

(14) Nas tabelas de exportações e importações, em razão dos diferentes números de anos envolvidos em cada um dos períodos analisados, foram introduzidas as médias anuais de cada fase.

(15) Estas percentagens foram calculadas em US\$ correntes, sobre o acumulado do período 1990-2004. 
Rogério Gomes / Eduardo Strachman / João Paulo Pieroni / Andréa de Oliveira Silva

2 e 4 a seguir e que foi confirmado em entrevistas), em que tanto importações quanto exportações crescem com o câmbio apreciado (período 1994-1998) e se reduzem a partir da desvalorização em 1999. O aumento das importações refletiu o impulso dado pela apreciação do Real, pela abertura agressiva da economia e pela queda drástica de alíquotas, as quais, somadas à maior tributação incidente sobre a produção nacional do que sobre a importada, implicava, paradoxalmente, proteção negativa aos produtos nacionais (Brasil, 2003a). Adicionalmente, houve o aumento da demanda da indústria têxtil do país, causado pelo breve ciclo expansivo pós-Plano Real (Laplane e Sarti, 1997; 1999), e antes atendida parcialmente pela indústria nacional de máquinas têxteis. Esses efeitos conjugados favoreceram as aquisições externas de bens de capital. Quando o curto ciclo expansivo tem seu fôlego definitivamente arrefecido, em 1998, ao que se combina a depreciação do câmbio, em janeiro de 1999, essas importações voltam a cair.

Tabela 2

Exportações brasileiras de máquinas têxteis: 1990-2004

\begin{tabular}{|c|c|c|c|c|c|c|}
\hline Máquinas & $\begin{array}{c}\text { Exportações } \\
\text { acumuladas } \\
\text { 1990-1993 } \\
\text { (US\$ mil) }\end{array}$ & $(\%)$ & $\begin{array}{c}\text { Exportações } \\
\text { acumuladas } \\
1994-1998 \\
\text { (US\$ mil) }\end{array}$ & $(\%)$ & $\begin{array}{c}\text { Exportações } \\
\text { acumuladas } \\
\text { 1999-2004 } \\
\text { (US\$ mil) }\end{array}$ & $(\%)$ \\
\hline $\begin{array}{l}\text { Máq. p/ tecidos sintéticos } \\
\text { e artificiais }\end{array}$ & 7.648 & 5,2 & 10.674 & 4,6 & 4.991 & 2,9 \\
\hline Média anual & 1.912 & - & 2.134 & - & 831 & - \\
\hline $\begin{array}{l}\text { Máq. p/ preparação de } \\
\text { fibras naturais }\end{array}$ & 20.930 & 14,1 & 45.487 & 19,4 & 26.147 & 15,4 \\
\hline Média anual & 5.232 & - & 9.097 & - & 4.358 & - \\
\hline Teares & 258 & 0,2 & 4.183 & 1,8 & 2.096 & 1,2 \\
\hline Média anual & 65 & - & 837 & - & 349 & - \\
\hline Teares para malhas & 1.403 & 0,9 & 7.042 & 3,0 & 7.728 & 4,6 \\
\hline Média anual & 351 & - & 1.409 & - & 1.288 & - \\
\hline $\begin{array}{l}\text { Peças, componentes e } \\
\text { acessórios }\end{array}$ & 34.073 & 23,0 & 87.240 & 37,2 & 68.891 & 40,7 \\
\hline Média anual & 8.518 & - & 17.448 & - & 11.482 & - \\
\hline Máq. de lavar e secar & 13.393 & 9,0 & 25.163 & 10,7 & 34.149 & 20,2 \\
\hline Média anual & 3.348 & - & 5.033 & - & 5.691 & - \\
\hline $\begin{array}{l}\text { Máq. de costura, peças e } \\
\text { componentes }\end{array}$ & 70.716 & 47,6 & 54.454 & 23,2 & 25.337 & 15,0 \\
\hline Média anual & 17.679 & - & 10.891 & - & 4.223 & - \\
\hline Total & 148.420 & 100,0 & 234.243 & 100,0 & 169.339 & 100,0 \\
\hline Média anual no período & 37.105 & - & 46.849 & - & 28.223 & - \\
\hline
\end{tabular}

Fonte: SECEX. Elaboração GEEIN. 
No tocante às exportações, as entrevistas realizadas junto às empresas de máquinas têxteis instaladas no país confirmaram que muitas dessas empresas teriam buscado novos mercados no exterior, especialmente os países da América Latina, como forma de sobrevivência, para compensar a forte concorrência de importados no mercado brasileiro, mesmo em uma conjuntura adversa, com a moeda nacional bastante apreciada. Corroborando essa opção, após a depreciação do Real, no início de 1999, e a maior dificuldade para importar, há um aumento da procura por máquinas nacionais, percebido em todo o período 1999-2004, o qual faz os fabricantes voltarem a deslocar sua produção para o mercado interno.

Com relação especificamente à pauta exportadora brasileira, aconteceram algumas mudanças significativas nos últimos 15 anos. As modificações relevantes podem ser explicadas, em boa medida, pelas mudanças nas estratégias das grandes empresas multinacionais do segmento, em razão da já referida maior exposição da indústria brasileira à concorrência internacional $\mathrm{e}$, em parte, pelas condições do mercado local.

A Tabela 2 mostra três grandes modificações na estrutura das exportações brasileiras de máquinas têxteis: 1) aumento expressivo da participação de peças, partes e componentes (NCM 8448); 2) perda da participação das máquinas de costura, suas partes e componentes (NCM 8452); 3) contínuo crescimento da participação das máquinas de acabamento, isto é, máquinas de lavar e secar (NCM 8451). ${ }^{16}$ Enquanto as duas primeiras alterações parecem confirmar a especialização verificada por Vermulm e Erber (2002) mencionadas acima, a última está relacionada com a capacitação da indústria metal-mecânica brasileira.

Ao segundo movimento cabe uma menção especial. Ele refere-se à perda da participação das máquinas de costura, suas partes e componentes (NCM 8452) na pauta exportadora, que diminui de quase 50\%, entre 1990-1993, para apenas $15 \%$, no último período. Ao longo do período, no tocante aos produtos desse código, houve uma redução significativa das vendas externas de máquinas, não observada no caso das peças e componentes. Nesse mesmo sentido, atualmente, o Brasil possui dois fabricantes de máquinas de costura, mas ambos estão, segundo as próprias empresas, reduzindo suas linhas de produção. Em resumo, além da forte redução das exportações desses produtos, houve um redirecionamento da manufatura, de produtos finais para peças e componentes de máquinas, como pode ser percebido na Tabela 3.

(16) Utilizamos, para efeito dos cálculos de comércio, apenas partes do código NCM 8451, referente a máquinas de lavar e secar, diferentemente dos outros códigos de comércio utilizado neste trabalho, que foram contabilizados de forma integral. A razão para este fato é que havia alguns produtos inseridos neste código que claramente não pertenciam à categoria de máquinas têxteis industriais. 
Rogério Gomes / Eduardo Strachman / João Paulo Pieroni / Andréa de Oliveira Silva

Tabela 3

Redução das exportações de máquinas de costura (US\$ mil)

\begin{tabular}{|c|c|c|c|}
\hline Produtos & $1990-1993$ & 1994-1998 & 1999-2004 \\
\hline Máquinas de costura & 50.914 & 26.589 & 6.012 \\
\hline Média anual & 12.729 & 5.318 & 1.002 \\
\hline Agulhas para máquinas de costura & 17.998 & 23.463 & 16.394 \\
\hline Média anual & 4.499 & 4.692 & 2.732 \\
\hline Partes de máquinas de costura & 1.804 & 4.402 & 2.931 \\
\hline Média anual & 451 & 880 & 489 \\
\hline Total & 70.716 & 54.454 & 25.337 \\
\hline Média anual & 17.679 & 10.891 & 4.223 \\
\hline
\end{tabular}

Fonte: Secex, Elaboração GEEIN.

A análise da estrutura da pauta exportadora brasileira traz outras revelações. A tecnologia de máquinas voltadas às fibras sintéticas (NCM 8444) historicamente não fez parte das estratégias dos empresários brasileiros. As firmas se especializaram, principalmente, em máquinas para tratamento de fios naturais, em especial de algodão, produto em que o país tem vantagens comparativas. Por esta razão, as exportações brasileiras destas últimas máquinas são significativamente superiores às das primeiras. No entanto, como a tendência da indústria têxtil internacional caminha em direção ao emprego de tecidos sintéticos, esta especialização ocorre em um segmento de comércio que se caracteriza pelo baixo dinamismo.

Tabela 4

Importações de máquinas têxteis: 1990-2004

\begin{tabular}{|c|c|c|c|c|c|c|}
\hline & $\begin{array}{c}\text { Importações } \\
\text { acumuladas } \\
\text { 1990-1993 } \\
\text { (US\$ mil) }\end{array}$ & $(\%)$ & $\begin{array}{c}\text { Importações } \\
\text { acumuladas } \\
\text { 1994-1998 } \\
\text { (US\$ mil) } \\
\end{array}$ & $(\%)$ & $\begin{array}{c}\text { Importações } \\
\text { acumuladas } \\
\text { 1999-2004 } \\
\text { (US\$ mil) }\end{array}$ & $(\%)$ \\
\hline $\begin{array}{l}\text { Máq. } \mathrm{p} / \text { tecidos sintéticos e } \\
\text { artificiais }\end{array}$ & 88.679 & 6,8 & 150.160 & 5,6 & 111.623 & 5,8 \\
\hline Média anual & 22.170 & - & 30.032 & - & 18.603 & - \\
\hline $\begin{array}{l}\text { Máq. p/ preparação de } \\
\text { fibras naturais }\end{array}$ & 213.574 & 16,3 & 458.977 & 17,1 & 394.783 & 20,5 \\
\hline Média anual & 53.393 & - & 91.795 & - & 65.797 & - \\
\hline Teares & 150.472 & 11,5 & 351.605 & 13,1 & 253.988 & 13,2 \\
\hline Média anual & 37.618 & - & 70.321 & - & 42.331 & - \\
\hline Teares para malhas & 227.025 & 17,3 & 556.333 & 20,7 & 305.041 & 15,8 \\
\hline
\end{tabular}


Tabela 4 - Continuação

\begin{tabular}{l|r|r|r|r|r|r}
\hline Máquina & $\begin{array}{c}\text { Importações } \\
\text { acumuladas } \\
1990-1993 \\
\text { (US\$ mil) }\end{array}$ & $(\%)$ & $\begin{array}{c}\text { Importações } \\
\text { acumuladas } \\
1994-1998 \\
\text { (US\$ mil) }\end{array}$ & $(\%)$ & $\begin{array}{r}\text { Importações } \\
\text { acumuladas } \\
1999-2004 \\
\text { (US\$ mil) }\end{array}$ & $(\%)$ \\
\hline Média anual & 56.756 & - & 111.266 & - & 50.840 & - \\
\hline $\begin{array}{l}\text { Peças, componentes e } \\
\text { acessórios }\end{array}$ & 262.971 & 20,1 & 334.532 & 12,4 & 316.027 & 16,4 \\
\hline Média anual & 65.743 & - & 66.906 & - & 52.671 & - \\
\hline Máq. de lavar e secar & 96.352 & 7,4 & 333.418 & 12,4 & 260.394 & 13,5 \\
\hline Média anual & 24.088 & - & 66.684 & - & 43.399 & - \\
\hline $\begin{array}{l}\text { Máq. de costura, peças e } \\
\text { componentes }\end{array}$ & 271.562 & 20,7 & 506.371 & 18,8 & 284.153 & 14,8 \\
\hline Média anual & 67.891 & - & 101.274 & - & 47.359 & - \\
\hline Total & 1.310 .634 & 100,0 & 2.691 .395 & 100,0 & 1.926 .009 & 100,0 \\
\hline Média anual no período & 327.659 & - & 538.279 & - & 321.002 & - \\
\hline
\end{tabular}

Fonte: SECEX. Elaboração GEEIN.

A abertura comercial dos anos 1990 apenas consagrou essa situação ao facilitar o deslocamento da produção das máquinas voltadas às fibras sintéticas para as matrizes no estrangeiro (ou suas subsidiárias na Europa), que passaram a abastecer o mercado local via importações. Isso explica a redução do peso das exportações desses bens na pauta comercial (Tabela 2).

A situação acima se altera um pouco quando se trata das máquinas para preparação de matérias têxteis (NCM 8445), que no caso brasileiro estão fortemente relacionadas à produção têxtil a partir de fibras de algodão. O parque industrial do país é, nesse segmento, comparativamente, mais expressivo, o que pode ser percebido pela importância relativa para o país das exportações dessas máquinas.

Apesar do processo de redução das empresas desse segmento (e da forte redução das vendas de máquinas e partes para o exterior), com o encerramento de algumas atividades realizadas localmente, como no caso das máquinas para o processo de abertura dos fardos (passadeira, maçaroqueiras e filatórias - ver Quadro 2), a importância desses produtos na exportação ainda se mantém, especialmente devido às máquinas ligadas às tecnologias do algodão - como as cardas, urdideiras e engomadeiras de fios.

A reestruturação desse segmento, embora com diminuição expressiva do número de empresas estabelecidas, parece ter sido positiva em termos de incorporação de tecnologia nas empresas que mantiveram sua produção. $\mathrm{O}$ conteúdo tecnológico das exportações aumentou e o das importações diminuiu, reduzindo a diferença de tecnologia entre as máquinas desse segmento produzidas no país e as oriundas do estrangeiro. No entanto, a conquista em termos de 
Rogério Gomes / Eduardo Strachman / João Paulo Pieroni / Andréa de Oliveira Silva

competitividade tecnológica (vide Tabela 5 - relação entre valor médio das exportações e importações) não foi superior à obtida pelas máquinas para tecidos artificiais. Em outras palavras, também nesse segmento, no qual o país apresentava potencial competitivo, os resultados foram bastante modestos.

Tabela 5

Conteúdo tecnológico do comércio exterior no Brasil: 1990-2004

\begin{tabular}{|c|c|c|c|c|c|c|c|c|c|}
\hline \multirow[t]{2}{*}{ Máquinas } & \multicolumn{3}{|c|}{$\begin{array}{l}\text { Valor Médio das } \\
\text { Exportações } \\
\text { (US\$ FOB/KG) }\end{array}$} & \multicolumn{3}{|c|}{$\begin{array}{l}\text { Valor Médio das } \\
\text { Importações } \\
\text { (US\$ FOB/ KG) }\end{array}$} & \multicolumn{3}{|c|}{$\begin{array}{l}\text { VM Exportações/VM } \\
\text { Importações }\end{array}$} \\
\hline & $90-93$ & $94-98$ & $99-04$ & $90-93$ & $94-98$ & 99-04 & $90-93$ & 94-98 & 99-04 \\
\hline $\begin{array}{l}\text { Máq. p/ tecidos sintéticos } \\
\text { e artificiais }\end{array}$ & 3,7 & 4,4 & 6,5 & 13,8 & 17,2 & 13,7 & 0,27 & 0,26 & 0,47 \\
\hline $\begin{array}{l}\text { Máq. p/ preparação de } \\
\text { fibras naturais }\end{array}$ & 3,1 & 3,2 & 5,0 & 15,3 & 14,1 & 10,7 & 0,20 & 0,23 & 0,47 \\
\hline Teares $^{(1)}$ & - & - & - & 16,7 & 15,0 & 9,6 & - & - & - \\
\hline Teares para malhas & 6,0 & 4,7 & 9,6 & 25,1 & 30,8 & 23,2 & 0,24 & 0,15 & 0,41 \\
\hline $\begin{array}{l}\text { Peças, componentes e } \\
\text { acessórios }\end{array}$ & 17,8 & 8,3 & 6,4 & 45,8 & 35,1 & 36,8 & 0,39 & 0,24 & 0,17 \\
\hline Máq. de lavar e secar & 11,4 & 12,0 & 9,6 & 19,8 & 16,8 & 15,3 & 0,58 & 0,71 & 0,63 \\
\hline $\begin{array}{l}\text { Máq. de costura, peças e } \\
\text { componentes }\end{array}$ & 18,6 & 27,1 & 46,9 & 22,6 & 19,3 & 10,9 & 0,82 & 1,40 & 4,30 \\
\hline
\end{tabular}

(1) Os dados para os teares, por serem pouco relevantes em termos de valores monetários, apresentavam grande amplitude de variação.

Fonte: SECEX. Elaboração GEEIN.

Os teares para tecidos (NCM 8446) e malhas (NCM 8447) são produtos com tecnologias mais avançadas, mais sofisticadas, que incorporam componentes da microeletrônica. Nesses dois produtos, o Brasil é, do ponto de vista tecnológico, claramente deficiente, como revelam a fragilidade das exportações e o vigor das importações (Tabela 3 ), especialmente no caso de teares para tecidos.

No caso dos teares para malhas, assim como para as máquinas de fibras naturais, a multinacional que permaneceu no país se reorganizou e ganhou competitividade. Por isso, o relativo fortalecimento das exportações e o conseqüente aumento da participação relativa e do conteúdo tecnológico das exportações (Tabela 2 e 5, respectivamente). No entanto, foi intensificada a já elevada dependência das aquisições feitas no estrangeiro. O Brasil possui apenas uma empresa produtora de teares circulares, necessitando demandar do exterior as outras categorias como os teares retilíneos, kettensthul, malimo, entre outros, o que explica tal dependência.

O segmento de máquinas auxiliares, peças e acessórios para as máquinas dos demais códigos (NCM 8448) é aquele em que o Brasil concentra o maior volume de vendas, superior a $40 \%$ do total das exportações atuais (Tabela 2). 
Porém, embora o Brasil tenha um leque de empresas bem desenvolvidas, as importações também são bastante elevadas (Tabela 4) e reveladoras da forte dependência por produtos estrangeiros mais sofisticados (Tabela 5), e mesmo de tecnologia estrangeira para a produção doméstica (grande diferença entre valor médio exportado e importado). Estas últimas observações foram confirmadas em uma entrevista com um importante fabricante totalmente brasileiro de acessórios para máquinas, o qual sublinhou que alguns componentes mais sofisticados de seus produtos provêm da Europa - inclusive por uma questão de escala - sendo apenas montados no país.

Nesse segmento, diferentemente de todos os demais de máquinas têxteis, a crescente concentração das vendas externas (especialização) esteve associada ao aumento da defasagem tecnológica (diminuição da relação entre o conteúdo tecnológico dos produtos exportados e importados), ao longo dos últimos 15 anos (Tabela 5). Em outras palavras, a reestruturação industrial parece ter sido perversa no segmento em que o país era mais avançado tecnologicamente. Se isso é verdadeiro, a nova divisão internacional do trabalho teria aprofundado as assimetrias anteriores e nesse segmento não teria ocorrido capacitação mais acentuada das empresas aqui instaladas, nacionais ou estrangeiras, de bens, serviços e partes mais sofisticadas.

Para os equipamentos para acabamento, como as máquinas de lavar $e$ secar (NCM 8451), o Brasil possui algumas empresas relevantes como a Texima e a Albrecht, ambas com exportações expressivas (superiores a US\$ 1 milhão, cada). ${ }^{17}$ Esses resultados são conseqüência da estratégia que as empresas do segmento adotaram, a partir da abertura comercial, de redução da sua gama de produtos, concentrando-se nos mais eficientes. ${ }^{18}$

Nessa fase de acabamento, o país apresenta indústrias relativamente eficientes, especialmente no tratamento de tecidos com os processos de lavagem, secagem e chamuscagem. As importações, nesse caso, visam às máquinas de estamparia, sem produção no Brasil.

Por fim, para as máquinas de costura, suas peças e componentes (NCM 8452), as empresas instaladas no país sempre foram tradicionais produtoras e exportadoras, como pode ser observado pela participação na pauta exportadora no início da década de 1990 (entre 1990 e 1993), quando as vendas externas desses produtos representavam a maioria da pauta brasileira. Ao longo dos anos 1990, porém, as exportações se reduziram sobremaneira, em boa medida devido à

(17) Dados disponíveis em <http://www.brazil4export.com/Br/Busca.asp>. Acesso em: 26 out. de 2005. Os dados disponíveis neste sítio são divididos por faixas de exportação, o que dificulta averiguar sua exatidão. As quatro faixas de exportação que compõem estes dados são: a) Até US\$ 1 milhão; b) De US\$ 1 milhão a 10 milhões; c) De US $\$ 10$ milhões a 50 milhões e: d) Acima de US\$ 50 milhões.

(18) Estes aspectos foram constatados pelos autores nas entrevistas com empresas do segmento. 
Rogério Gomes / Eduardo Strachman / João Paulo Pieroni / Andréa de Oliveira Silva

diminuição das vendas das máquinas de costura (Tabela 3). Atualmente, o Brasil possui dois fabricantes de máquinas de costura, embora ambos estejam, segundo as próprias empresas, reduzindo suas linhas de produção.

Além disso, no segmento específico de máquinas de costura, peças e componentes de máquinas ocorre um fato único dentro da indústria (e raro no comércio exterior do país): o conteúdo tecnológico das exportações é superior ao das importações. Entretanto, como foi mencionado, grande parte da redução das vendas externas da indústria de máquinas têxteis foi causada pela queda das exportações das máquinas de costura, o que foi acompanhado por um concomitante aumento da importância relativa das exportações dos produtos classificados como peças, componentes e acessórios. Dessa forma, ainda que o país tenha avançado tecnologicamente no segmento, como nos informam os valores médios, esse avanço se restringiu a produtos menos dinâmicos no mercado internacional.

Em síntese, houve uma forte especialização das exportações domésticas em direção a produtos intermediários (partes, peças e acessórios de máquinas) dos diferentes segmentos da indústria. Essa característica é extensiva, também, aos segmentos nos quais o Brasil era bastante eficiente no início dos anos 1990, como, por exemplo, os de máquinas para acabamento e máquinas de costura.

Não obstante, em termos de conteúdo tecnológico incorporado, os valores médios indicam o avanço tecnológico em alguns dos produtos exportados (Tabela 4), ${ }^{19}$ como máquinas para tecidos sintéticos e artificiais, máquinas para preparação de matérias têxteis, teares para malhas e máquinas de costura, o que seria um indício dos efeitos benéficos da abertura comercial sobre a eficiência e a tecnologia dos produtos brasileiros. Porém, essa conclusão precisa ser relativizada em razão da redução do volume das vendas externas ao longo do período (-25\%). Além disso, como em vários segmentos as atividades realizadas no país foram reduzidas à confecção de partes e componentes e outras máquinas, houve um retrocesso na capacitação da indústria brasileira de máquinas têxteis devido à perda de conhecimento na produção e no desenvolvimento de produtos finais mais complexos. Também por isso, a recente integração internacional foi desfavorável à indústria nacional.

Além disso, ainda que a estratégia de redução da gama de produtos tenha servido para aumentar a competitividade e preservar parte das vendas externas (Tabela 2), esse mecanismo não evitou a forte elevação das importações, especialmente no período de apreciação do câmbio, uma característica comum da indústria de máquinas têxteis.

(19) O conteúdo tecnológico das importações diminuiu mais intensamente que o das exportações, significando uma diminuição da defasagem tecnológica entre os produtos vendidos e os adquiridos pelo país. 


\section{Considerações finais}

Em boa medida explicado pelas correntes imigratórias ocorridas no final do século XIX e início do XX, a indústria e as empresas nacionais de máquinas têxteis do Brasil tiveram seu desenvolvimento fortemente atrelado à capacitação técnica e às firmas dos países europeus, em especial as da Itália e Alemanha. No entanto, após um período de intenso protecionismo, com origem na chamada "crise da dívida" do início dos anos 1980, toda a economia do Brasil iniciou, ao final desse período, um processo de liberalização que transformou profundamente a estrutura industrial do país.

Em razão dessas mudanças, da rapidez com que foram implantadas juntamente com políticas econômicas fortemente contracionistas, as quais incluem períodos de rápida apreciação da moeda nacional - e da fragilidade das empresas locais (muito pouco internacionalizadas), houve uma forte desnacionalização de uma importante parcela dessa economia e uma transferência de vários segmentos industriais do país para o estrangeiro, seguindo as estratégias das empresas multinacionais presentes no país (Furtado, 2003). Ainda que isso tenha resultado em modernização de alguns setores industriais, o controle de importantes companhias do Brasil pelo capital estrangeiro, assim como a referida mudança no posicionamento das multinacionais, já de longa data presentes no país, alteraram significativamente as estratégias de um conjunto fundamental de empresas e a própria capacidade do Estado em promover políticas industriais.

Em algumas indústrias brasileiras, como, por exemplo, de equipamentos de telecomunicações (Galina, 2004; Gomes, 2003) e de equipamentos mecânicos, elétricos e motores elétricos (Avellar, 2004; Strachman, 2004; Strachman e Avellar, 2006), alguns impactos daquelas políticas foram positivos, ao menos a partir de meados dos anos 1990, seja pela (re)definição dos mandatos das filiais dentro da rede corporativa, seja pela introdução/ampliação de atividades tecnológicas realizadas por essas filiais. Com isso, de certa forma, pôde-se ao menos contrabalançar parcialmente uma série de impactos negativos dessa abertura acentuada, da desproteção industrial e das políticas macroeconômicas francamente restritivas, as quais mostraram suas conseqüências, por exemplo, no baixo crescimento econômico e, sobretudo, industrial, em todo o período pós1980.

No que tange ao setor de máquinas têxteis, a maior integração do país com a economia internacional teve implicações específicas. Primeiramente, há evidências de que esse setor, em âmbito mundial, esteja se concentrando em países que dispõem de elevado potencial de desenvolvimento de novas tecnologias e que precisam atingir elevada escala de vendas, tanto para viabilizar esses desenvolvimentos - via elevados investimentos em P\&D - quanto para conseguirem reduções de custos. Esse processo igualmente teve início há tempos, 
nos anos 1960 (Rothwell, 1982; Pieroni, 2005), sendo acelerado com os avanços na microeletrônica, sobretudo a partir dos anos 1980. Como a estrutura industrial brasileira é deficiente no que se refere a esses componentes, o processo de internacionalização e descentralização produtiva do setor de máquinas têxteis em direção ao Brasil parece ter sido não só estancado, mas revertido, com uma transferência estratégica por parte das empresas multinacionais da produção dos bens de maior conteúdo tecnológico de volta para suas matrizes.

A associação dessa tendência com a abertura comercial brasileira acelerada e sem salvaguardas implicou uma redução do setor de máquinas têxteis do país, com diminuição da gama de produtos fabricados no país e/ou paralisação dos negócios pelas firmas que anteriormente aqui produziam máquinas e equipamentos para diferentes etapas do processo produtivo têxtil.

A maioria dessas empresas era produtora de máquinas para a etapa de fiação, aparentemente o segmento mais afetado com a diminuição do número de empresas (ver Quadro 3) e aquele no qual o Brasil poderia gozar de mais vantagens da interação entre produtor e usuário (especialmente em fibras naturais - Lundvall, 1988). No entanto, a abertura comercial e o deslocamento pelas companhias multinacionais de importantes funções corporativas antes realizadas no país implicaram, como explicamos, a redução e a concentração ${ }^{20}$ do setor de máquinas têxteis do país como um todo.

Quadro 3

Abertura comercial e integração internacional: competitividade da indústria brasileira de máquinas têxteis, 1989 e 2004

\begin{tabular}{|c|c|c|c|}
\hline $\begin{array}{l}\text { Processo } \\
\text { produtivo têxtil }\end{array}$ & Máquina & $\begin{array}{l}\text { Situação antes das reformas } \\
\text { dos anos } 90\end{array}$ & Situação em 2004 \\
\hline \multirow{4}{*}{ Fiação } & Cardas & $\begin{array}{l}\text { Competitiva; pequena defasagem } \\
\text { com a tecnologia estrangeira }\end{array}$ & $\begin{array}{l}\text { Alta tecnologia; em } \\
\text { sintonia com os } \\
\text { produtos estrangeiros }\end{array}$ \\
\hline & Passadeira & $\begin{array}{c}\text { Pouco competitiva; grande } \\
\text { defasagem com a tecnologia } \\
\text { estrangeira }\end{array}$ & Inexistente \\
\hline & Maçaroqueiras & $\begin{array}{c}\text { Pouco competitiva; grande } \\
\text { defasagem com a tecnologia } \\
\text { estrangeira }\end{array}$ & Inexistente $^{(1)}$ \\
\hline & Filatórios & $\begin{array}{c}\text { Pouco competitiva; grande } \\
\text { defasagem com a tecnologia } \\
\text { estrangeira }\end{array}$ & Inexistente \\
\hline
\end{tabular}

Continua...

(20) A produção nacional caiu de $\mathrm{R} \$ 336$ milhões, em 1990, para pouco mais de $\mathrm{R} \$ 200$ milhões, em 2002 (Revista Textília, n. 40). 
Quadro 3 - Continuação

\begin{tabular}{|c|c|c|c|}
\hline $\begin{array}{l}\text { Processo } \\
\text { produtivo têxtil }\end{array}$ & Máquina & $\begin{array}{c}\text { Situação antes das reformas } \\
\text { dos anos } 90\end{array}$ & Situação em 2004 \\
\hline \multirow{3}{*}{$\begin{array}{l}\text { Preparação para } \\
\text { a Tecelagem }\end{array}$} & Conicaleira & $\begin{array}{l}\text { Pouco competitiva; grande } \\
\text { defasagem com a tecnologia } \\
\text { estrangeira }\end{array}$ & Inexistente \\
\hline & Urdideiras & $\begin{array}{c}\text { Média Competitividade; } \\
\text { pequena defasagem tecnológica }\end{array}$ & $\begin{array}{c}\text { Média Competitividade; } \\
\text { pequena defasagem } \\
\text { tecnológica }\end{array}$ \\
\hline & $\begin{array}{l}\text { Engomadeira de } \\
\text { fios }\end{array}$ & $\begin{array}{c}\text { Média Competitividade; } \\
\text { pequena defasagem tecnológica }\end{array}$ & $\begin{array}{c}\text { Média Competitividade; } \\
\text { pequena defasagem } \\
\text { tecnológica }\end{array}$ \\
\hline \multirow{2}{*}{$\begin{array}{l}\text { Teares para } \\
\text { trama e urdume }\end{array}$} & Teares a jato de ar & Não competitiva & Inexistente ${ }^{(1)}$ \\
\hline & Teares de pinça & Não competitiva & Inexistente \\
\hline \multirow{3}{*}{$\begin{array}{l}\text { Fabricação de } \\
\text { malhas }\end{array}$} & $\begin{array}{l}\text { Teares para } \\
\text { malhas }\end{array}$ & $\begin{array}{c}\text { Média Competitividade; } \\
\text { pequena defasagem tecnológica }\end{array}$ & $\begin{array}{l}\text { Competitiva; em } \\
\text { sintonia com os } \\
\text { produtos estrangeiros }\end{array}$ \\
\hline & $\begin{array}{l}\text { Máquinas para } \\
\text { acabamento }\end{array}$ & $\begin{array}{c}\text { Competitiva; relativamente } \\
\text { eficientes }\end{array}$ & $\begin{array}{l}\text { Competitiva; } \\
\text { relativamente eficientes }\end{array}$ \\
\hline & $\begin{array}{l}\text { Máquinas para } \\
\text { estamparia }\end{array}$ & Inexistente & Inexistente \\
\hline $\begin{array}{l}\text { Beneficiamento } \\
\text { de malharia }\end{array}$ & $\begin{array}{l}\text { Máquinas para } \\
\text { centrifugação e } \\
\text { pressão }\end{array}$ & $\begin{array}{c}\text { Média Competitividade; } \\
\text { pequena defasagem tecnológica }\end{array}$ & $\begin{array}{c}\text { Média Competitividade; } \\
\text { pequena defasagem } \\
\text { tecnológica }\end{array}$ \\
\hline
\end{tabular}

(1) Não foi possível verificar se a Toyota, recém-instalada no país, terá produção local ou apenas comercializará produtos importados da matriz.

Fonte: CNI (2000), revistas especializadas e entrevistas com empresas do setor. Elaboração GEEIN.

Embora tenham ocorrido aumentos significativos no conteúdo tecnológico de algumas máquinas comercializadas pelo país, esse efeito benéfico não se refletiu, como vimos, em aumentos no volume exportado. Além disso, houve um direcionamento da produção para produtos menos dinâmicos no comércio internacional, especialmente peças, partes e componentes, como pôde ser observado para o segmento de máquinas de costura.

$\mathrm{Na}$ atual inserção internacional, o Brasil continua exportando, em sua maior parte, equipamentos para a indústria têxtil de menor valor agregado, principalmente peças e acessórios de máquinas. Isso sugere, uma vez mais, uma especialização do país em produtos de menor conteúdo tecnológico, complementando com partes e peças fabricadas localmente as sofisticadas máquinas européias e japonesas. Como vimos neste artigo, essa participação estrangeira é relativamente maior quanto mais elevado o conteúdo tecnológico dos produtos, como no caso dos teares baseados na microeletrônica - uma vez mais um calcanhar-de-aquiles da economia nacional - em que a indústria brasileira praticamente cessou a sua produção. Dessa forma, a integração do país com o 
Rogério Gomes / Eduardo Strachman / João Paulo Pieroni / Andréa de Oliveira Silva

exterior é bastante forte e subordinada, especialmente, aos países da União Européia, contrastando com alguns avanços em termos de autonomia produtiva e tecnológica alcançados em outros setores industriais.

\section{Referências}

AVELLAR, A.P. Relatório Final DPP-FINEP para o Setor de Bens de Capital. Araraquara: Unesp. Faculdade de Ciências e Letras, 2004. Mimeografado.

BASTOS, V. Competitividade do complexo têxtil: estudo da competitividade da indústria brasileira. Campinas: Unicamp, 1993. Relatório de pesquisa. Mimeografado. Disponível em: <http://www.mct.gov.br/publi/Compet/ntc_tex.pdf>. Acesso em: 3 mar. 2005.

BNDES. Proposta de política para apoio e modernização e expansão do setor têxtil. Rio de Janeiro: BNDES/DEEST, 1986. Relatório de Pesquisa.

BRASIL. Ministério da Fazenda. Impactos da mudança do regime de tributação da Cofins. Brasília: Minifaz, 2003a. Mimeografado. $<$ www.fazenda.gov.br/portugues/releases/2003/NOTA\%20PIS\%20SE\%20-\%2004-12c.pdf>.

. Ministério do Desenvolvimento, Indústria e Comércio. Diretrizes de política industrial. Brasília: MDIC, 2003b. Mimeografado.

CANTIZANI FILHO, A. Diagnóstico da competitividade internacional do setor de máquinas e equipamentos. São Paulo: Abimaq/Sindimaq, ago. 1997. Mimeografado.

CONFEDERAÇÃO NACIONAL DA INDÚSTRIA - CNI. Análise da eficiência econômica da competitividade da cadeia têxtil brasileira. Brasília: CNI/ IEL, Sebrae, 2000. Mimeografado. Disponível em: $<$ www.iel.cni.org.br/html/cadeias_produtivas_têxtil.htm>

CORRÊA, D. G. Setor têxtil luta pela sobrevivência. Revista ABIMAQ, São Paulo, n. 46, ano 12, p. 46, 1998.

COUTINHO, L. A especialização regressiva: um balanço do desempenho industrial pósestabilização. In: VELLOSO, J. P. R. Brasil: desafios de um país em transformação. Rio de Janeiro: J. Olympio, 1997.

DIRETÓRIO DA PESQUISA PRIVADA NO BRASIL - DPP. Araraquara, Campinas. DPP-FINEP-GEEIN-DPCT, 2003. Disponível em: <http://www.finep.gov.br/portaldpp>.

FIANI, R. Teoria dos custos de transação. In: KUPFER, D.; HASENCLEVER, L. (Org.). Economia industrial: fundamentos teóricos e práticas no Brasil. Rio de Janeiro: Campus, 2002. p. 267-286.

FURTADO, J. Introdução. In: FURTADO, J. (Org.). Globalização das cadeias produtivas do Brasil. São Carlos: Ed. UFSCar, 2003.

et al. Balanço de pagamentos tecnológicos: indicadores e análise. In: INDICADORES de Ciência, Tecnologia e Inovação do Estado de São Paulo. São Paulo: Fapesp, 2002. 
GALINA, S. Relatório Final DPP-FINEP para o Setor de Equipamentos para Telecomunicações. Araraquara: Unesp. Faculdade de Ciências e Letras, 2004. Mimeografado.

GARCIA, O. L. Análise da indústria brasileira de máquinas e acessórios têxteis. Relatório de Pesquisa IPT/Fecamp/Unicamp. Campinas: Unicamp. IE, 1990.

Competitividade da indústria têxtil. Relatório de Pesquisa do Projeto "Estudo da Competitividade da Indústria Brasileira". Campinas: Unicamp. IE, 1993. Mimeografado. Disponível em: $<$ http://www.mct.gov.br/publi/Compet/nts_tex.pdf $>$.

Avaliação da competitividade da indústria têxtil brasileira. 1994. Tese (Doutorado)-Instituto de Economia, Universidade Estadual de Campinas, Campinas, 1994.

GOMES, R. A internacionalização das atividades tecnológicas pelas empresas Transnacionais: elementos de organização industrial da economia da inovação. Ph.D. Dissertation, Instituto de Economia, Universidade Estadual de Campinas (IE-Unicamp). Campinas, 2003. Mimeografado.

; RODRIGUES, H.; CARVALHO, E. G. Balanço de pagamentos tecnológicos: o perfil do comércio externo de produtos e de serviços com conteúdo tecnológico. In: INDICADORES de Ciência e Tecnologia do Estado de São Paulo - 2004. São Paulo: Fapesp, 2005.

GORINI, A. P. F. Panorama do setor têxtil no Brasil e no mundo: reestruturação e perspectivas. Texto para o Fórum de Competitividade do Ministério do Desenvolvimento, Indústria e Comércio Exterior. BNDES Setorial, Rio de Janeiro, n. 12, p. 17-50, set. 2000.

HIRATUKA, C. Um estudo sobre a capacitação tecnológica da indústria de máquinas têxteis e suas relações com a indústria têxtil. Monografia (Conclusão do curso de Ciências Econômicas)- Faculdade de Ciências e Letras, Unesp, Araraquara, dez. 1992.

Estruturas de coordenação na cadeia têxtil: um estudo sobre as relações entre a indústria têxtil e os fornecedores de fibras químicas, fibras de algodão e máquinas têxteis. Dissertação (Mestrado)-Instituto de Economia, Unicamp, Campinas, 1996.

JAPAN emphasis remains on development. Textile Month. p. 33, 1988.

JAPANESE textile machinery cost to merge synthetic fiber units. Asia Paulse News, Osaka, Jan., p. 308, 2002.

LAPLANE, M. F.; SARTI, F. Investimento direto estrangeiro e a retomada do crescimento sustentado nos anos 90. Economia e Sociedade, Campinas, n. 8, 1997.

- Investimento Direto Estrangeiro e o impacto na balança comercial nos anos

90. Rio de Janeiro: Ipea, 1999. (Texto para Discussão, n. 629).

LUNDVALL, B.Å. Innovation as an interactive process: from user-producer interaction to the National System of Innovation. In: DOSI, G.; FREEMAN, C.; NELSON, R.; SILVERBERG, G.; SOETE, L. (Org.). Technical change and economic theory. London: Pinter, 1988. p. 349-369.

MARRONE, P. Rumos da competitividade: uma política industrial para o setor de máquinas e equipamentos. São Paulo: ABIMAQ, 2003. 
Rogério Gomes / Eduardo Strachman / João Paulo Pieroni / Andréa de Oliveira Silva

MARRONE, P. Atualização e ampliação da abrangência no cálculo do nível de competitividade dos segmentos do setor de máquinas e equipamentos. São Paulo: Consultrend/Abimaq, 2004.

; MARÇAL, E. F.; MARÇAL, L. H. Estimativa estatística de metas para os segmentos do setor de máquinas e equipamentos mediante a implementação das ações de política industrial. São Paulo: Consultrend/Abimaq, 2004.

MARSILI, O. The anatomy and evolution of industry: technological change and industrial dynamics. Cheltenham: Edward Elgar, 2001.

MASSUDA, E. M. Transformações recentes da indústria têxtil brasileira (1992-1999). Acta Scientiarum, Maringá, v. 24, n. 1, p. 243-251, 2002.

MOREIRA, M. M.; CORREA, P. G. Abertura comercial e indústria: o que se pode esperar e o que se vem obtendo. Revista de Economia Política, São Paulo, v. 17, p. 61-91, 1997.

OLIVEIRA, M. H.; MEDEIROS, L. A. Investimentos necessários para a modernização do Setor Têxtil. BNDES Setorial, Rio de Janeiro, BNDES, n. 3, 1996.

PAVITT, K. Sectoral patterns of technical change: towards a taxonomy and a theory. Research Policy, v. 13, n. 6, p. 343-373, 1984.

PIERONI, J. P. Os impactos da abertura comercial sobre as estruturas produtiva e tecnológica do setor de máquinas têxteis no Brasil. Monografia (Conclusão do curso de Ciências Econômicas)- Faculdade de Ciências e Letras, Unesp, Araraquara, dez. 2005.

PONDÉ, J. L. Coordenação e aprendizado: elementos para uma teoria das inovações institucionais nas firmas e nos mercados. Dissertação (Mestrado)-Instituto de Economia, Unicamp, Campinas, 1993. Mimeografado.

Organização das grandes corporações. In: KUPFER, D.; HASENCLEVER, L. (Org.). Economia industrial: fundamentos teóricos e práticas no Brasil. Rio de Janeiro: Campus, 2002. p. 287-306.

PROCHNIK, V. Estudo da competitividade de cadeias integradas no Brasil: impactos das zonas de livre comércio. Cadeia: Têxtil e Confecções. Campinas: Unicamp. IE e MDIC, dez. 2002.

PROMATECH acquires Sulzer Textil. The Financial Times, Companies e Finance International. Jul. p. 16, 2001.

RESENDE, M. F. C.; ANDERSON, P. Mudanças estruturais na indústria de bens de capital. Brasília: Ipea, jul. 1999. (Texto para Discussão, n. 658).

REVISTA TEXTÍLIA, n. 40, 2001.

REVISTA TEXTÍLIA, n. 46, 2002.

RIETER, Acquires German Textile Machinery Firma. Daily News Record, Geneva, p. 6, Apr. 2001.

ROTHWELL, R. Innovation in textile machinery. In: PAVITT, K. Technical innovation and British performance. London: SPRU, MacMillan, 1982. 
SIGIURA, K. The technological role of machinery users in economic development: the case of textile machinery industry in Japan and Korea. Thesis (Phd)-University of Sussex, 1994.

SIMON, H. A. The architecture of complexity. Proceedings of the American Philosophical Society, v. 106, n. 6, p. 467-482, Dec. 1962.

The architecture of complexity. Proceedings of the American Philosophical Society, v. 106, n. 6, p. 467-482, Dec. 1962.

From substantive to procedural rationality. In: LATSIS, S. J. (Ed.). Method and appraisal in economics. Cambridge: Cambridge University Press, 1976. p. 129-148.

STRACHMAN, E. Relatório Final DPP-FINEP para o Setor de Equipamentos Elétricos sob Encomenda. Araraquara: Unesp. Faculdade de Ciências e Letras, 2004. Mimeografado.

; AVELLAR, A. P. Estratégias, desenvolvimento tecnológico e inovação no setor de bens de capital no Brasil. Araraquara, 2006. Mimeografado.

TOYNE, A. The global textile industry. London: George Allen \& Unwin Publishers Ltda., 1984.

VERMULM, R.; ERBER, F. Estudo da competitividade de cadeias integradas no Brasil: impactos das zonas de livre comércio. Cadeia: Bens de Capital. Campinas: Unicamp. IE e MDIC, dez. 2002. 